\title{
Mentha atrolilacina (Lamiaceae), a new species from South Australia
}

\author{
Barry J. Conn ${ }^{1}$ and Daniel J. Duval ${ }^{2}$ \\ ${ }^{1}$ National Herbarium of New South Wales, Mrs Macquaries Road, Sydney NSW 2000, Australia \\ Email: barry.conn@rbgsyd.nsw.gov.au \\ ${ }^{2}$ SA Seed Conservation Centre, Botanic Gardens of Adelaide, North Terrace, Adelaide SA 5000, \\ Australia \\ Email: daniel.duval@sa.gov.au
}

\begin{abstract}
The new species Mentha atrolilacina B.J.Conn and D.J.Duval (Lamiaceae) from south-eastern South Australia is here described. This species is morphologically similar to M. diemenica Sprengel, but can be distinguished by its flowers with a dark lilac corolla (cf. M. diemenica often purple to pale purple); corolla short, 3-3.5 mm long (cf. M. diemenica 4-7 mm long); anthers included (cf. M. diemenica \pm distinctly exserted); petioles short, $0.8-1.5 \mathrm{~mm}$ long (cf. M. diemenica c. $3 \mathrm{~mm}$ long).
\end{abstract}

\section{Introduction}

The genus Mentha L. (Lamiaceae) consists of mostly perennial herbs and subshrubs in the tribe Mentheae (Harley in Harley et al. 2004). The genus comprises about 20 species in damp, open habitats, especially in the Mediterranean and Australasian regions (Harley in Harley et al. 2004). Prior to the discovery of M. atrolilacina, four species were recognised as naturally occurring in Australia, with an additional six species introduced and regarded as naturalised (Conn 1992, 1999).

Mentha atrolilacina B.J.Conn and D.J.Duval sp. nov.

a M. diemenica R.Br. corollis brevioribus (3-3.5 mm longis) atrolilacinis, antheris inclusis differt.

Holotype: South Australia: South-eastern: Honans Scrub Native Forest Reserve, 12 Dec 2007, D.J. Duval 1017 (AD220419; iso.: NSW860729).

Etymology: from Latin atrolilacinus, dark lilac, referring to the dark lilac coloration of the corolla lobes.

Small herb up to c. $55 \mathrm{~cm}$ high; stem and branches moderately hairy, hairs simple, curled, \pm antrorse (at least distally), 0.07-0.1 mm long, with scattered longer hairs $0.17-0.24 \mathrm{~mm}$ long. Leaves aromatic when crushed; petiole $0.8-1.5 \mathrm{~mm}$ long, slender, shortly hairy (hairs $0.05-0.07 \mathrm{~mm}$ long); lamina membranous, ovate to broadly ovate, 
6-11 mm long, 5-10 mm wide (length to width ratio 1-1.6); minutely hairy, with scattered long, multicellular hairs, especially on veins, moderately glandular (glands hemispherical); base shortly cordate; margin entire; apex rounded. Inflorescences consisting of 3- or 4-flowered simple cymes in distal leaf axils, leaves subtending inflorescence reduced (petiole 0.6-0.7 mm long; lamina ovate, 1.2-2.8 mm long, 0.4-1 mm wide, hairy and glandular as for mature leaves, base cuneate, margin entire, apex obtuse). Podium 0.7-1 mm long; prophylls linear (widest near middle) c. $2 \mathrm{~mm}$ long, 0.1-0.2 mm wide, surface hairy, with hairs simple, spreading to slightly retrorse, base long-attenuate, apex acuminate. Calyx 3.3-3.5 mm long, outer surface hairy, hairs white, $0.07-0.1 \mathrm{~mm}$ long, spreading to slightly retrorse; tube c. $2.5 \mathrm{~mm}$ long, 12-ribbed (especially when dried), mid-green to maroon, inner surface glabrous; lobes triangular, $0.8-1 \mathrm{~mm}$ long, $0.8-0.9 \mathrm{~mm}$ wide, with maroon tinge, margin and inner distal surface with long white hairs (0.4-0.5 mm long), apex subacute. Corolla dark lilac, 3-3.5 mm long; tube c. $2 \mathrm{~mm}$ long, distinctly paler than lobes, outer surface glabrous or with a few scattered hairs, inner surface glabrous; lobes \pm equal, ovate, basally abruptly narrowed and straight-sided, outer surface sparsely hairy, glabrous near margin, inner surface glabrous, with margin entire and slightly undulate, abaxial lobe slightly angular-ovate distally, 1.5-1.8 mm long, c. $1.2 \mathrm{~mm}$ wide apex rounded, lateral lobes 1-1.4 $\mathrm{mm}$ long, 0.8-0.9 mm wide, apex rounded; adaxial lobe $0.8 \mathrm{~mm}$ long, $1-1.2 \mathrm{~mm}$ wide, 2-lobed, sinus c. $0.3 \mathrm{~mm}$ long. Stamens included to slightly exserted; filaments up to c. $0.1 \mathrm{~mm}$ long, pale lilac, glabrous; anthers $0.4-0.5 \mathrm{~mm}$ long, blue-mauve to pale brown. Disk c. $0.1 \mathrm{~mm}$ long; ovary c. $0.5 \mathrm{~mm}$ long, green, distal lobes up to c. $0.1 \mathrm{~mm}$ long; style 1.5-1.8 mm long, distally curved towards abaxial corolla lobe, dark lilac to almost white (basally); stigma c. $0.3 \mathrm{~mm}$ long, lobes 2, linear. Mericarps not known. Figs $1 \& 2$.

Distribution: this taxon is only known from the Honans Native Forest Reserve, approximately $16 \mathrm{~km}$ north-west of Mount Gambier, in the South-eastern region of South Australia.

Ecology: this species is scattered throughout Eucalyptus ovata-dominated woodland with an understorey of Poa labillardierei, Mentha diemenica, Arthropodium milleflorum and Eryngium vesiculosum. The reserve, previously known as Honans Scrub (ForestrySA 2005), contains 1,030 hectares of native vegetation consisting of Eucalyptus baxteri, E. obliqua, E. ovata, E. viminalis subsp. cygnetensis and E. willisii subsp. falciformis (ForestrySA 2005). Additional populations of this species have, as yet, not been located. However, it is thought that this species is likely to occur in nearby reserves and extend to western Victoria.

Conservation status: unknown.

Notes: Mentha atrolilacina is morphologically similar to the species of the Mentha satureioides complex, namely M. satureioides R.Br. and M. diemenica Sprengel (Conn 1992, 1999), and to M. pulegium L. (Toelken 1986). All four species have hairs on the margin of the calyx lobes. The inner surface of the throat of the calyx tube is hairy in M. pulegium, whereas the entire inner surface of the calyx tube is glabrous in the other species. The stamens are included in M. atrolilacina, but are exserted in the other species. The broader cordate leaves of $M$. atrolilacina are readily distinguishable from those of M. diemenica (Fig. 3).

The corolla lobes become \pm strongly recurved when the flower is in the female phase (anthers \pm dehisced) and the stigmatic lobes become strongly recurved after fertilisation. 


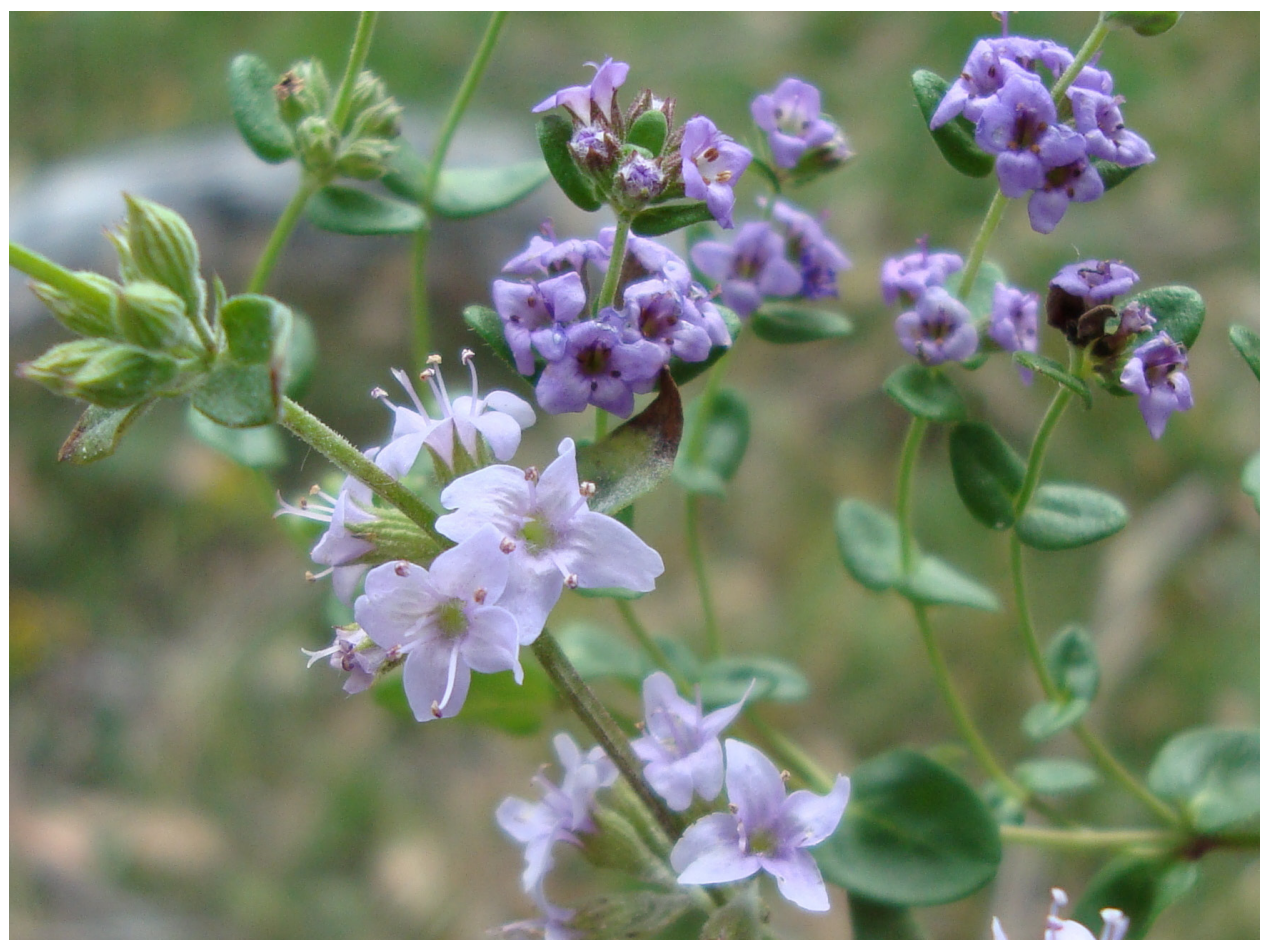

Fig. 1. Habit photograph of Mentha diemenica Spreng. (foreground) and Mentha atrolilacina B.J.Conn \& D.J.Duval (background), illustrating corolla colour (the former species has a much paler corolla than M. atrolilacina), size and shape differences.

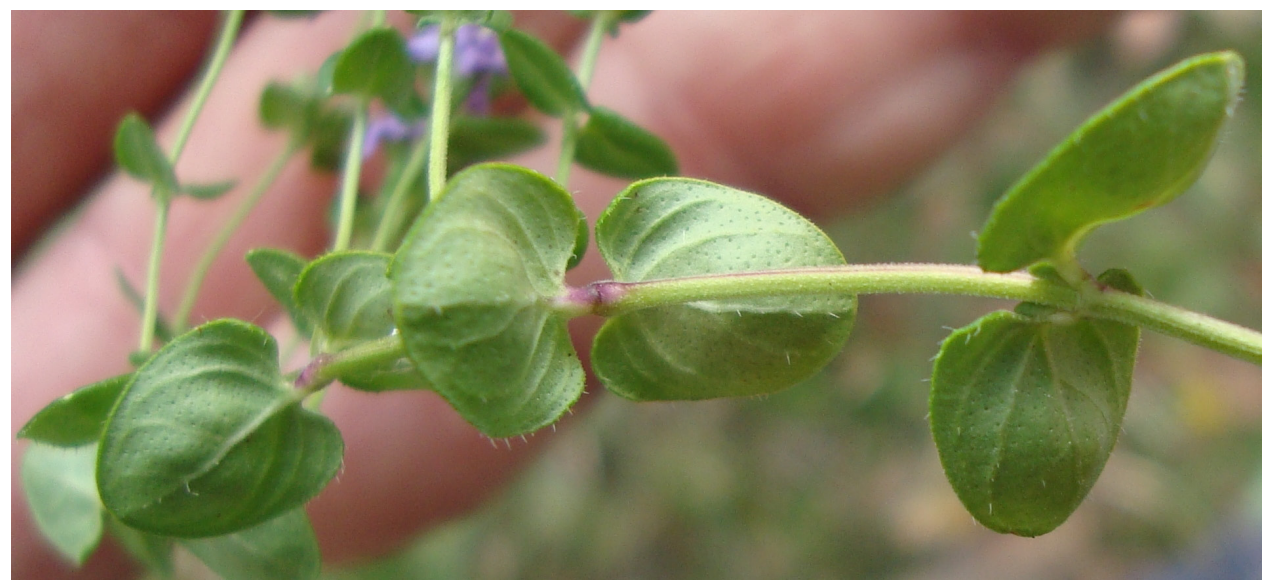

Fig. 2. Photograph of abaxial surface of leaves of Mentha atrolilacina illustrating ovate to broadly ovate lamina, with scattered long, multicellular hairs on veins and margin, hemispherical glands hemispherical, and shortly cordate base. 


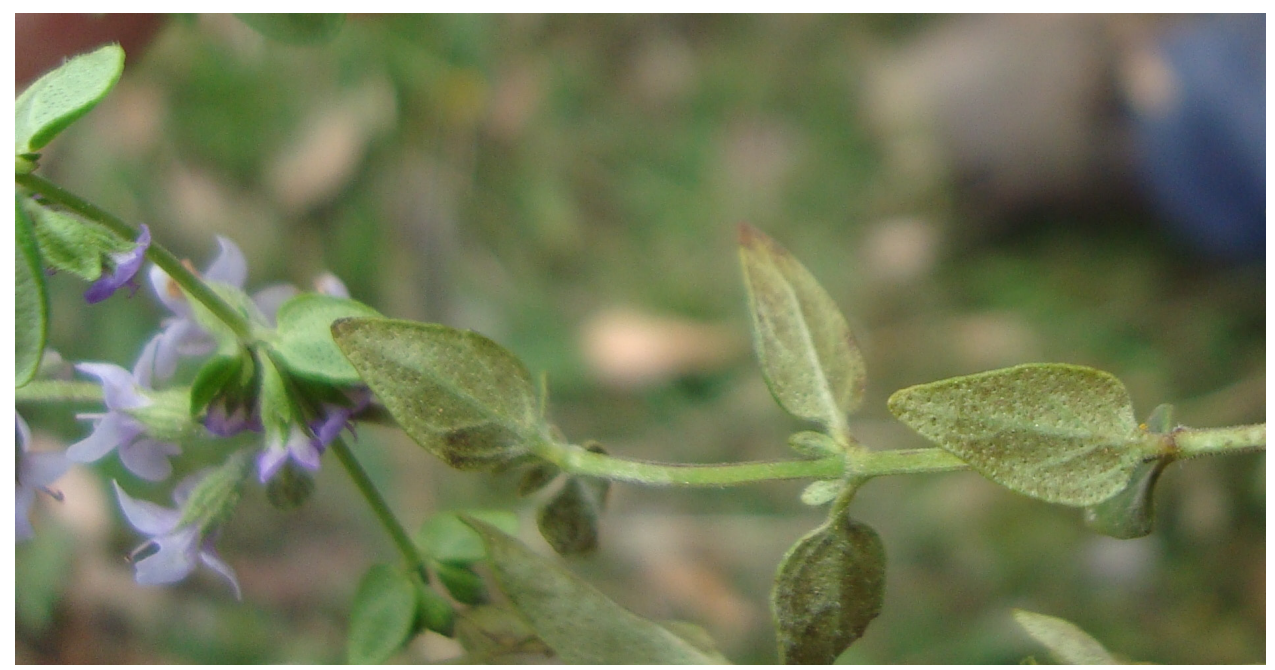

Fig. 3. Photograph of abaxial surface of leaves of Mentha diemenica illustrating ovate lamina, hemispherical glands, and rounded base.

Other specimens examined: South Australia: South-eastern: Honans Native Forest Reserve, 7 Dec 2006, D.J. Duval 724 (AD); 21 Nov 2007, D.J. Duval 974 (AD); 12 Dec 2007, D.J. Duval 1017 (AD); 10 Jan 2007, T.S. Te 155 (AD, MEL).

\section{References}

ForestrySA (2005) Honan Native Forest Reserve revised management plan. (ForestrySA: Mount Gambier)

Harley RM (2004) Labiatae VII. 2. Tribe Mentheae Dumort. (1827). Pp. 230-250 in Harley RM, Atkins S, Budantsev AL, Cantino PD, Conn BJ, Grayer R, Harley MM, Kok R de, Krestovskaja T, Morales R, Paton AJ, Ryding $\mathrm{O}$ and Upson T The families and genera of vascular plants, vol. VII Flowering plants. Dicotyledons - Lamiales (except Acanthaceae, including Avicenniaceae). (Springer: Berlin)

Conn BJ (1992) Lamiaceae. Pp. 623-664 in Harden GJ (ed.) Flora of New South Wales, vol. 3. (New South Wales University Press: Kensington)

Conn BJ (1999) Lamiaceae. Pp. 418-459 in Walsh NG and Entwisle TJ (eds) Flora of Victoria, vol. 4. (Inkata Press: Melbourne)

Toelken HR (1986) Labiatae. Pp. 1192-1232 in Jessop JP and Toelken HR (eds) Flora of South Australia, part III. (South Australian Government Printing Division: Adelaide)

Manuscript received 12 May 2010, accepted 21 June 2010 